\title{
Jnhalt des II. Bantoes.
}

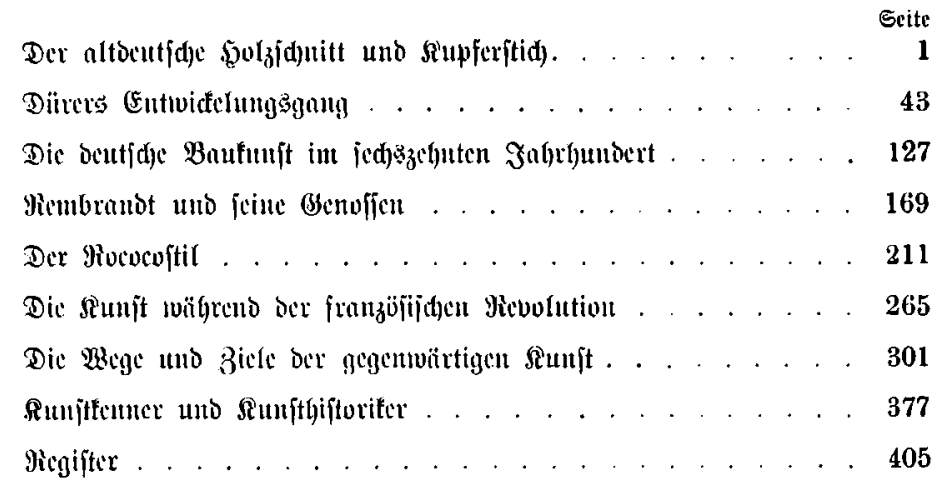

